\title{
Att läsa mellan raderna på metafiktion. Om flickskapets aktörskap i Alice's Adventures in Wonderland
}

\author{
Hilma Olsson
}

Det är knappt så att vi hinner lägga märke till dem, ögonblicken som passerar strax innan Alice försvinner ner i Underlandet i inledningsraderna till Lewis Carrolls barnboksklassiker, Alice’s Adventures in Wonderland. ${ }^{1}$ Det går så snabbt. Men faktum är att det är i dessa ögonblick som magin inträffar och historien kan börja veckla ut sig: Det är en tämligen trist och vanlig dag i 1800-talets England när Alice börjar få nog av att sitta uttråkad på stranden bredvid sin syster som fastnat med näsan djupt nedsjunken i en, i Alices tycke, helt meningslös roman. Inga bilder, ingen konversation, inte den minsta tillstymmelse till liv eller rörelse på boksidorna. Hon sneglar över systerns axel då och då, försöker åtminstone förstå vad hon ser bortom de nedplitade bokstäverna. Till sist får Alice nog. Hon lyfter blicken och låter tankarna vandra fritt längs flodkanten. Då plötsligt ser hon den. Kaninen som kommer jäktandes mellan några träd och som så småningom ska ledsaga henne ner i Underlandet. Då upplever hon det, som hon för bara ett par sekunder sedan inte kunde se på boksidorna, ”på riktigt” framför sig. Då kan äventyret börja!

\section{Metafiktion och makt}

I den här artikeln avser jag att studera hur olika aspekter av makt, agens och flickskap aktualiseras med utgångpunkt i Alices uppvisning av metafiktion. Inledningsscenen jag beskrivit här ovan - en av nyckelsymbolerna för hela romanens metafiktiva tema - kan förstås som metafiktiv av tre huvudsakliga anledningar. För det första tematiserar den läsning och uppmuntrar oss läsare att bli uppmärksamma på hur vi själva läser romanen - om vi som Alice har svårt att få ihop orden till levande meningar, eller mer som hennes syster, ser något bortom ordens lexikala innebörd. Den får oss också att vilja härma Alice genom att fundera över romanens form och hur den är berättad: finns det några bilder? Innehåller texten dialog?

För det andra representerar Alice och hennes syster varsin abstraktion av språkets betecknande potential: antingen blir orden, som för Alice, inget mer än ett system av konventionellt ordnade tecken, så kallade "words”, eller så lyckas de iscensätta eller förmedla upplevelsen av riktiga världar, så kallade "worlds”, vilket är hur Alices syster verkar uppleva sin roman (Waugh, 1984: 10).

Det tredje skälet har att göra med att Alice själv är medveten om att berättelsevärlden hon befinner sig i är en fantasi. Hennes förhållande till Underlandet är således mycket likt

\footnotetext{
${ }^{1}$ Vidare omnämns titeln endast med Alice. Inte att förväxla med ”Alice” (utan kursivering) då jag istället syftar på henne som karaktär.
} 
läsarens förhållande till romanen - hon är medveten om dess fiktivitet och parallella existens med den "egentliga verkligheten".

Det är med ett samlat grepp om dessa tre anledningar som jag vill studera vilka frågor och potentiella svar om makt och flickförakt, som romanen erbjuder genom sin uppvisning av metafiktion. Patricia Waughs renommerade Metafiction (1984) är min teoretiska bas för metafiktionsbegreppet jag använder.

Så vad är då syftet med att göra denna sammankoppling mellan metafiktion och makt? Vad säger det om Alice som inte redan sagts? Att metafiktiv litteratur för med sig en rad maktrelaterade konsekvenser är något som är väl känt, inte minst ur ett läsarorienterat perspektiv inom barnlitteratur. Detta gör det särskilt angeläget att läsa Alice med utgångspunkt i en maktanalys. Ofta känner barn inte till de litterära konventioner som metafiktionen anspelar på. Därför finns risken att den metafiktiva effekten passerar över huvudet på barnet (McCullum 1999:139). Det är sällan önskvärt, åtminstone i vår tids strävan efter aktiva läsare inom barnlitteraturen.

Den franska litteraturforskaren Virginie Iché har med utgångspunkt i detta receptionsteoretiska fält studerat läsarens inflytande över läsakten i artikeln, "Submission and Agency, or the Role of the Reader in the First Editions of Lewis Carroll's Alice's Adventures in Wonderland (1865) and Through the Looking-Glass (1871) och kommit fram till att Carroll inbjuder läsaren att interagera med berättelsen genom att använda sig av ett intermedialt berättargrepp. Som exempel nämner hon bläddringen, vilken Iché menar påbjuder läsaren ett aktörskap med förmågan att realisera den skrivna texten (Iché 2016: 9). Det sker dock inte utan att läsaren samtidigt måste underordna sig berättarens instruerande läsanvisningar, där till exempel samspelet mellan bild och text spelar en viktig roll, enligt Iché (Iché 2016:7).

Iché undersöker alltså maktförhållandet mellan läsaren och texten i ett receptionsteoretiskt gränssnitt som har blivit det allra vanligaste sättet att närma sig Alice i nyare litteraturforskning. Om detta skriver även Jeffery Howard i en artikel från 2015,"What is the use of a book... without pictures?: Images and words in Alice's Adventures in Wonderland". Mitt sätt att läsa Alice är av ett något annorlunda slag. Istället för att undersöka metafiktionens exponering av makt och dess betydelse för läsaren, vill jag studera relationen mellan metafiktion och makt på tematisk nivå - det vill säga vilka konsekvenser maktordningen får för huvudkaraktären Alice i romanen. Att metafiktionen går att skönja på de här två olika nivåerna i Alice beror i sig på att metafiktionsbegreppet är föremål för en omtvistad definitionsdiskussion. Bör metafiktion betraktas som ett stilgrepp som redan finns inuti texten eller som en effekt som uppstår i mötet mellan läsaren och texten? I min analys utgår jag från att metafiktionen är en redan befintlig företeelse i texten, inte för att det nödvändigtvis behöver vara så utan för att det öppnar för en läsning som gör det möjligt att analysera de tematiska aspekterna av makt och metafiktion - något som det hittills forskats betydligt mindre på. Det är dock oundvikligt att helt bortse från det läsarorienterade perspektivet. Alices och hennes förhållande till makt uppvisar nämligen stora likheter med den så kallade "verkliga läsaren”, vilket även Waughs användning av begreppet bäddar för. Hon menar att metafiktiv litteratur synliggör berättande på ett sätt som problematiserar hur vi med språkets hjälp skapar mer eller mindre fiktiva världar i vår egen verklighet (Waugh 1984:18). Själv använder jag den receptionsteoretiska Alice-forskningen som en 
markeringspenna med vilken jag understryker och belyser mina iakttagelser av tematiseringen av metafiktion och makt.

\section{Flickskapets aktörskap}

Om då makt och metafiktion går att förstå som ett orsakssamband på tematisk nivå, är det primärt inte vilka konsekvenser detta får för läsaren utan för Alice själv som jag avser studera. Jag har valt att förstå Alice och hennes roll i romanen i egenskap av flicka, dels för att det är det genus hon tillskriver sig själv av romanberättaren, dels för att jag anser att detta är en av romanens grundpremisser. I min analys antar jag både Alices och berättarens blick på vad flickskap är och borde vara för att belysa det dubbla förtryck som Alices utsätts för. På så vis kan jag få syn på ambivalensen i Alices relation till sig själv och andra flickor, som präglas av både yttre och inre förväntningar, förtryck och förakt. Kombinationen av metafiktion och makt blir ett sätt att förstå och fördjupa komplexiteten i Alices flickskap. Genom att ta hänsyn till Alices särskildhet i egenskap av barn och flicka, placerar jag in Alice i ett "flicktivt" sammanhang, det vill säga, i ett teoretiskt fält som kombinerar flickforskning och studier av fiktion. Begreppet myntades av redaktörerna till antologin Flicktion perspektiv på flickan i fiktionen (2013) och överensstämmer med min bild av Alice och hur hennes flickskap porträtteras i romanen: "Vi vill med begreppet flicktion ringa in flickskildringar som innehåller ett moment av förändring, förnyelse, en rörelse mot eller en antydan om en mer komplex gestaltning” (Söderberg, Österlund och Formark 2013: 14f). I samma antologi skriver Jenny Jarlsdotter-Wikström en artikel om Alices kroppsliga aktörskap men går inte in på hur detta - eller det verbala - hänger ihop med romanens metafiktion, det vill säga Alices medvetenhet om sig själv som fånge i en berättelsevärld. Till skillnad från Jarlsdotter-Wikström kommer jag att undersöka hur Alice med sitt samlade aktörskap förhåller sig till det påbjudna händelseförloppet i romanen och så småningom lyckas ta kontroll över berättelsen. Med den här artikeln blir mitt bidrag till den redan befintliga och mycket omfattande Alice-forskningen att visa att romanen har inslag av både flicktion och metafiktion. Alices uppvisning av "metaflicktion” är en ännu outforskad dimension.

Ytterligare en anledning till varför metafiktion och makt kan kombineras är att Alices aktörskap både realiserar och blir realiserad genom berättandet i romanen. Med aktörskap menar jag att Alice på olika sätt tar kontroll över händelseförloppet, både kroppsligen och verbalt, vilket är vad jag kommer att undersöka. Att läsa Alice, inte i första hand som språklig konstruktion, utan som kropp - reaktiv och aktiv, kännande och kommunicerande - har varit viktigt för att ta hänsyn till hennes utsatthet som barn och flicka även inom litteraturens världar. Berättaren i Alice, liksom i många andra romaner, använder Alices ålder och genus för att förstärka önskvärda variabler av hennes identitet och aktörskap. Dessa mått på "storlek”, "kunskap” och "flickföreställningar” är också viktiga för Alice när hon värderar sig själv och i hur hon ser på andra flickor. För mig har det viktigaste varit att inte frånta Alice sin kompexitet eller, som så många gånger i och av litteraturen, reducera henne till en projektionsyta för binära dualiteter (Jarlsdotter-Wikström 2013:91). Alices motsägelsefullhet - genom att till exempel vara lika ofta den som hånar andra som hånas själv - har tvärtom varit en viktig utgångpunkt i min analys eftersom det visar att makt och förtryck inte är en 
enkelriktad handling som utförs av en förtryckare mot någon som blir förtryckt. Istället uppträder makt i intrikata rörelsemönster som ur ett flickperspektiv till exempel blir synligt genom flickors tendens att klandra eller straffa sig själva när de blir förtryckta.

\section{Disposition}

Analysen har jag delat in i tre avsnitt. I första delen står metafiktionen i centrum. Jag diskuterar varför och hur romanen Alice kan förstås som metafiktiv och på vilket sätt det hänger ihop med karaktären Alices aktörskap. I avsnitt två beskriver jag det hot under vilket Alice svävar att ständigt bli fråntagen sitt aktörskap. Genom att studera interaktionen mellan metafiktion och makt och Alices språkliga förmåga framträder betydelsen av hennes roll i egenskap av flicka. I tredje delen gör jag plats för kroppen och dess metafiktiva potential för att visa att det så småningom är med den som Alice återerövrar sitt aktörskap.

Avslutningsvis reflekterar jag över metafiktionens betydelse i min egen analys. Jag diskuterar begreppets olika meningsmöjligheter och föreslår att mitt sätt att använda metafiktionen öppnar för en ny applikation.

\section{En läsare eller en företrädare för läsare?}

Att förstå Alice som en protagonist, medveten om berättelsen hon är fångad i, är kanske den tydligaste uppvisningen av metafiktion som romanen erbjuder. Alice jämför och funderar över relationen mellan Underlandet och verkligheten, och gränsen för var dessa verklighetsnivåer går är så tydlig att Alice kan förrumsliga den i sina tankar:

\footnotetext{
'It'll be no use their putting their heads down and saying “Come up again, dear!” I shall only look up and say "Who am I then? Tell me that first, and then, if I like being that person, I'll come up: if not, I'll stay down here till I'm somebody else” - but, oh dear!' cried Alice, with a sudden burst of tears, 'I do wish they would put their heads down! I am so very tired of being all alone here!' (Carroll 2015:16, artikelförfattarens fetmarkeringar)
}

Genom att placera verklighetnivåerna längs en vertikal linje avslöjar Alice inte bara Underlandets underordnade verklighetsstatus i förhållande till verkligheten ovan, hon synliggör också berättelsens narrativa konstruktion genom att antyda att hon själv skulle vara ett slags verklig läsare som råkat trilla ner i boksidorna under läsakten. Alice växlar mellan att acceptera och ifrågasätta de absurda inslagen i Underlandet på samma sätt som den "verkliga läsaren" måste godta orimligheten av vissa fakta som aldrig skulle accepteras i den egna verkligheten. För dem båda är detta villkoret för att Underlandet överhuvudtaget ska kunna existera: läsaren av Alice måste ge romanen legitimitet som verklig i sitt eget litterära sammanhang trots bristande logik och avsaknad av realistiska skildringar (Waugh 1984: 95). På samma sätt tvingas Alice sålla bland orimligheterna i Underlandet och reagerar ibland starkt på vissa, ibland inte alls på andra. Ett exempel är när hon blir provocerad av att de vita rosorna målas röda i Drottningens trädgård samtidigt som hon inte alls reflekterar över det faktum att det är spelkort ur en kortlek som utför arbetet, vilket borde vara ännu mer provocerande (Carroll 2015: 62).

Passager där Alice mer direkt tematiseras som läsare eller lyssnare finns det också i romanen. Metafiktionen tar sig då vanligtvis i uttryck explicit genom att berättargreppet 
förändras och blir till vers, ikonisk dikt eller sång, eller via tempoväxlingar som uppstår när Alice ställer frågor och skapar så kallade "disturbances” eller avbrott som hjälper till att synliggöra berättandet som aktivitet (Waugh 1984: 82). Ett exempel på detta är när Alice introduceras för den falska sköldpaddan (Mock Turtle) som ska berätta om sitt tragiska förflutna för henne. Hela scenen utspelar sig på tolv sidor, vilket är relativt långt i sammanhanget då Alice vanligtvis byter miljö efter fem till sex sidor. Effekten blir att läsaren upplever en långsamhet som liknar den som Alice blir så provocerad av när sköldpaddan aldrig kommer igång med sitt berättande. Till sist inleder sköldpaddan med att uppmana sina åhörare att inte avbryta honom förrän han berättat sin historia klart. När han efter en lång paus på nytt tar till orda är det ändå precis vad Alice gör. Hon ställer först en fråga, sedan en till, och sedan ytterligare en och fortsätter så tills de måste avbryta eftersom rättegången börjar. Efter tolv långa sidor av stilmässiga avbrott i form av inskjutna sånger, rim och verser har sköldpaddan fortfarande inte berättat sin historia till slutet. Resultatet blir att den upplevs som ännu långsammare, svårbegriplig och osammanhängande - för Alice såväl som för läsaren av Alice. ${ }^{2}$

Scenen med den falska sköldpaddan stör alltså på både tematisk och formmässig nivå: å ena sidan genom bristen på logik och konsekvens i sköldpaddans berättelse vilket gör Alice otålig och frustrerad, å andra sidan genom att inte leva upp till de förväntningar som läsaren har på romanen som meningsskapande, följsam och begriplig. Passagen är en förtätning eller miniatyr av Underlandets övergripande berättarstruktur: det är inte Alices svårighet att hänga med i Sköldpaddans berättelse som gestaltas i första hand. Istället är det hur läsaren tvingas kämpa med det fragmentariska och nonsensinspirerade berättandet i romanen i stort som scenen med Sköldpaddan illustrerar. På ett liknande sätt förstår också Zadworna-Fjellestad de mindre inslagen i Alice som en duplicering av romanens metafiktiva tematik i avhandlingen Alice's Adventures in Wonderland and Gravity's Rainbow. A study in duplex fiction (1986), som är en av de få vetenskapliga publikationer som studerat Alices uppvisning av metafiktion. Det egentliga äventyret i Alice, menar Zadworna-Fjellestad, är inte hennes upplevelser i Underlandet utan läsningen som ett äventyr i sig (Zadworna-Fjellestad 1986: 36).

Jag delar uppfattningen att läsning är ett av Alices huvudsakliga teman och att det realiseras på flera olika nivåer i berättelsen. Alice är mycket lik en läsare, vilket jag velat visa genom mina exempel ovan, men skiljer sig från den "verkliga läsaren” på en viktig punkt: när Alice tror sig vara tillbaka i verkligheten, det vill säga, hos systern på stranden, vet den verkliga läsaren att hon måste tränga genom ytterligare ett verklighetslager för att lämna den fiktiva världen helt. Det gör hon inte. Det är det här som gör Alice som karaktär fiktiv och Alice som roman metafiktiv. På det sättet kan Alice aldrig bli men däremot företräda sina läsare, vilket hon gör genom att anta deras verklighetsperspektiv. När hon konfronterar

\footnotetext{
${ }^{2}$ I konstrast till detta motvilliga och frågvisa sätt att förhålla sig till berättande står Hertiginnan. Hon är istället alldeles för bejakande och inställsam och urholkar på så sätt ordens specifika betydelse vilket gör att de så småningom upphör att betyda något alls (Carroll 2015: 73). Trots att de har motsatta hållningar leder deras agerande till samma sak: kommunikationen fungerar inte. Återigen ställs Alice inför det faktum att det måste råda en balans mellan ifrågasättandet och acceptans - dels för att kunna kommunicera och begripliggöra märkvärdigheterna i Underlandet och dels för att världen ska hållas intakt och inte förlora sin villkorliga verklighetsstatus.
} 
varelserna i Underlandet är det med frågor som hennes läsare egentligen vill - men inte kan ställa till dem. Att Alice kallar Underlandet för "queer” är ytterligare ett tecken på att hon använder verklighetens normer som jämförelsegrund till det underliga och absurda. Queerheten framträder först när hon sätter det i perspektiv med vad hon anser vara det realistiska.

Medan Alice demaskerar Underlandets fiktivitet, steg för steg, blir det för läsaren mer och mer tydligt att romanen framstår som en fiktiv artefakt. Även här företräder Alice sin implicita läsare. Hon använder sin agens för att infiltrera, styra och så småningom också avsluta berättelsen. Agensen är såväl fysisk som verbal. På samma sätt som Alice ställer frågor, avbryter eller föreslår egna fortsättningar på romanen, bläddrar och hoppar över partier, använder hon kroppen (som det så småningom ska framgå) för att driva handlingen i en viss riktning. Slutet på romanen understryker denna betydelse av delaktighet. När Alice inser att hennes inflytande är underordnat drottningens i berättelsen, bestämmer hon sig helt enkelt för att sluta tro på den. Och vad händer då? Alice vaknar och illusionen om Underlandet upphör. På samma sätt kan texter med metafiktiv karaktär sägas "väcka” den ”verkliga läsaren” och avslöja fiktiviteten i läsarens egen värld. Det är här som metafiktion och verklighet förenas, menar Waugh. Avslöjandena sker parallellt. Från att ha enbart gällt litteraturens fiktiva världar blir metafiktionen nu en påminnelse om att hela världen byggs upp med hjälp av betydelser i språket. Enligt henne bör vi vara lika vaksamma på verklighetens som fiktionens språk och vara ständigt beredda på att det fiktionaliserar verkligheten i någon mån (Waugh 1984: 3).

Som företrädare för sina läsare får Alice och betydelsen av hennes metafiktiva funktion en helt annan tyngd. Hon agerar språkrör för en målgrupp som vanligtvis inte själv har möjligheten att uttrycka sig i tryckt eller fiktiv skrift. Carrolls roman är inte på något sätt unik i den bemärkelsen att den skulle vara skriven på större inflytande av barn än någon annan barnlitterär roman. Däremot gestaltar den aktörskap på ett sätt som väcker frågor kring barns rätt att delta i berättandet av romanen, och det gör den åtminstone unik för sin tid. ${ }^{3}$ Idag är vi mer vana vid att se barn som aktiva och medskapande aktörer som ibland till och med kan få vara med och bestämma över utkomsten av en berättelse. I den bemärkelsen förtjänar Alice att kallas något "modern”. Hon är vare sig en svag företrädare för sina läsare eller en passiv protagonist. Tvärtom är det genom hennes nyfikenhet och kreativitet, genom hennes verbala och kroppsliga förmåga, som intrigen slutligen avgörs i romanen. Men hennes inflytande står sällan oemotsagt. Lika ofta som hon tar för sig och bereder plats, riskerar hon att fråntas sitt aktörskap. I de två kommande avsnitten vill jag visa på hur Alices makt utmanas, men också vilka olika strategier hon använder för att återvinna den.

\section{Det hotade aktörskapet}

Låt oss återgå till Alice och hennes syster på stranden i inledningsscenen. Efter att ha försökt fastna för innehållet i systerns bok - och misslyckats - prövar Alice om inte verkligheten kan

\footnotetext{
${ }^{3}$ Detta är ett påstående som även Iché ställer sig bakom. Hon menar att Carroll placerar in sig i en brytpunkt mitt emellan två litteraturtraditioner genom att dels använda ett didaktiskt berättargrepp (där nonsenstematiken fungerar som ett pedagogiskt språkverktyg), dels inkludera läsaren i berättandet med hjälp av bläddring samt samspelet mellan bild och text (Iché, 2016: 13).
} 
ge henne något roligare. Och visst kan den det. Snart har den levt upp till de kriterier som systerns bok sakande: den innehåller en synlig (bilder) kanin som talar (dialog) och jäktar (spänning och rörelser) över gräsmattan. Det är tillräckligt för att väcka Alices nyfikenhet. Hon bestämmer sig för att jaga efter kaninen och trillar strax därefter ner i ett litet hål. Sett ur det här perspektivet skulle Alice mycket väl kunna vara den som själv blåser liv i omgivningen med hjälp av fantasin. Det är också högst troligt att det är till sin egen föreställningsvärld hon anländer efter att ha dykt ner i Underlandet, snarare än någon annans fiktiva verklighet.

Samtidigt är det av uppenbara skäl ett inte helt sant påstående. Alice är trots allt huvudkaraktär i Lewis Carrolls verk, inte i sitt eget. Dessutom är hon inte den som själv berättar om sina äventyr i Underlandet. Upplevelserna återges av en allvetande berättare som knappast drar sig för att markera närvaro i romanen genom att kommentera och tillgodose läsaren med den information om Alice som händelserna i Underlandet inte själv avslöjar (Zadworna-Fjellestad 1986: 27). I själva verket löper berättarens översitteri och förhärskande kommentarer som en röd tråd genom berättelsen för att påminna Alice - trots hennes på många sätt självbemäktigande aktörskap - att hon inte har full kontroll över vad som händer i romanen. Dessa kommentarer fungerar som ett metafiktivt inslag i berättandet genom att uppmärksamma läsaren på fiktionens olika verklighetsnivåer, det vill säga, att Alice har befunnit sig i en annan värld före ankomsten till Underlandet: "Alice had been to the seaside once in her life [...]” (Carroll 2015: 17). Men kanske än viktigare påminner de läsaren om sin egen roll som läsare genom att berättaren riktar sig direkt till sin publik: "And as you might like to try the thing yourself, some winterday, I will tell you how the Dodo managed it." (Carroll 2015: 21, artikelförfattarens fetmarkeringar)

Förutom, eller kanske samtidigt som dessa kommentarer är metafiktiva, är de ett led i den kamp om inflytande och makt som både Alice och berättaren gör anspråk på. Kommentarerna är då snarare en "show-off” där berättaren får visa hur mycket mer hen vet om Underlandet än vad både Alice själv och läsaren gör. En liknande uppvisning av makt äger rum när berättaren gör sig lustig på Alices bekostnad när hon försöker förklara underligheterna i Underlandet med ord hon själv inte förstår. ${ }^{4}$

Berättaren verkar tycka att Alice tror för mycket på sig själv och hånar henne för att vara förnumstig, det vill säga, för mycket "vuxen” i ett barns kropp. Inte heller när hon misslyckas, när hon till exempel glömmer ta ned nyckeln från bordet innan hon krymper sin kropp, är hon lagom smart eller lagom mycket barn. Istället beskrivs Alice som "the poor little thing" (min kursiv) som "sat down and cried" efter att ha "tired herself out from trying” (Carroll 2015: 12). På det här sättet polariseras Alice och blir en projektionsyta för en föreställning om en "lagomhet” perfekt balanserad mellan två olika ytterligheter: att vara försigkommen men inte för försigkommen. Alice har också för vana att värdera sig själv utefter sina prestationer, vilket blir tydligt i hur nöjd hon är med sig själv när hon lyckas komma på rätt juridisk term för jurymedlemmarna under rättegångsscenen: ”'I suppose they are the jurors.' She said the last word two or three times over to herself, being rather proud of

\footnotetext{
${ }^{4}$ Ett exempel är när Alice försöker räkna ut var hon befinner sig efter så många timmars fall och undrar vilken höjd- och breddgrad Underlandet ligger på. Berättaren kommenterar: ”Alice had no idea what Latitude was, or Longitude either, but thought they were nice grand words to say.” (Carroll 2015: 8)
} 
it: for she thought, and rightly too, that very few girls in her age knew the meaning of it all." (Carroll 2015: 88).

Som citatet ovan visar på är det alltid flickor som Alice jämför sig med när hon värderar sina prestationer. Väl införstådd med alla de förväntningar som följer som en bipacksedel till hennes flickskap, missar Alice aldrig ett tillfälle att kritisera sig själv eller andra flickor när de inte lyckas vara på det sätt som hon anser flickor borde. Ett exempel på detta är flickan Mabel som Alice (på grund av att hon är fattig och korkad) är livrädd för att förväxlas med (Carol 2015: 16). Alice kan således sägas ha approprierat sin förtryckares - det vill säga berättarens - blick vilket resulterar i ett självförakt som beror på förlusten av kontroll över vem hon är och vad hon kan. I förlängningen blir detta även ett flickförakt då hennes sätt att återta kontrollen över sig själv blir genom att distansera sig till flickorna hon inte vill vara.

Som så många andra kvinnor förr förväntas Alice alltså leva upp till en omöjlighet - att integrera motsägelser utan att framstå som skev och ambivalent. Resultatet blir en knäckfråga. "Att prestera eller inte prestera" har likheter med "hora-madonna-komplexet" som bygger på en liknande, paradoxal tankestruktur. Genom att både förutsätta och förvänta att kvinnan har en sexualitet ska hon samtidigt förnekas och förvägras rätten att visa upp den. Alice är fångad mellan ytterligheterna i just en sådan dualitet, eftersom det är där flickskapet definieras och så småningom accepteras, inte minst av henne själv.

Jarlsdotter-Wikström menar att Underlandet i själva verket är tillflyktsorten från en sådan dualitet (Jarlsdotter-Wikström 2013: 91) medan jag är mindre hoppfull och läser både berättaren och Alice själv som ytterst närvarande representanter för den verklighet som Alice i så fall försöker fly. De tar med sig paradoxen ner i Underlandet och romanens metafiktiva anspelningar hjälper dem att få syn på den. När Alice upptäcker att hennes prestationer inte räknas i Underlandet blir hon så rädd att förändringen ska permanentas och påverka hennes status som flicka att hon hellre önskar vara ensam kvar i Underlandet än att komma upp i verkligheten som någon annan (Carroll 2015: 16).

En vanlig tolkning är att Alices sviktande självförtroende bör förstås som ett uttryck för den identitetsförlust hon upplever på grund av Underlandets brist på mening och struktur. ${ }^{5}$ Själv förstår jag nonsenstematiken och språkförbristningarna i Alice inte lika mycket som en konsekvens av Alices identitetsförlust som ett uttryck för Underlandets motvilja att acceptera Alice som hon är. Det är inte bara för sina ord och handlingar som Alice måste stå till svars utan lika ofta för sig själv och vem hon är:

'But I am not a serpent, I tell you!' said Alice. 'I'm a... I'm a...'

'Well! What are you?' said the Pigeon. 'I can see you're trying to invent something!'

'I... I'm a little girl', said Alice, rather doubtfully, as she remembered the number of changes she had gone through the day. (Carroll 2015: 43)

Trots absurditeten i det faktum att Alice förväntas hålla ihop och polarisera dikotomiska kategorier utan att själv för den delen verka motsägelsefull, är det oftare sig själv än

\footnotetext{
${ }^{5}$ Som en naturlig följd av detta föreslår Gilles Deleuze, som har skrivit just om meningsskapandets logik med utgångspunkt i Alice, att Alice också förlorar tillgången till ett fungerande språk eftersom språket existerar i beroende av en identitet som ju Alice saknar (Deleuze, Gilles. Logic of Sense, Columbia University Press, New York, 1990: 79). En annan tolkning gör Jarlsdotter-Wikström som snarare vänder på kausaliteten och förstår Alices identitetsförlust som en konsekvens av Underlandets obeständighet och flytande subjektobjektrelationer (Jarlsdotter-Wikström 2013: 91).
} 
omgivningen hon klandrar när hon inte presterar som hon önskar: "'You ought to be ashamed of yourself', said Alice” (Carroll 2015: 13) eller "'Oh, you foolish Alice'! she answered herself.” (Carroll 2015: 29). Alices förväntningar på sig själv stämmer således överens med berättarens förväntningar på Alice vilket resulterar i ytterligare ett förtryck: det som utövas av henne själv mot sig själv.

\section{Aktörskapet återerövras}

Att bara se Alice som självförtryckande och förtryckt ger ingen rättvis bild av hennes aktörskap. Faktum är att hon på flera sätt gör motstånd, till exempel genom att ställa frågor, som jag visade i exemplet med den falska sköldpaddan. Aktivismen kan på det här sättet betraktas som verbal. Alice använder sig av sin språkliga förmåga för att tillbakavisa Underlandets påbjudna meningslöshet, vilket accentueras när hon vid flera tillfällen i boken kommenterar eller intar rollen som berättande aktör. ${ }^{6}$ På så vis kan hon göra Underlandet begripligt igen.

En av slutsatserna som Zadworna-Fjellestad drar är att Alice - trots sina många gånger språkliga förbristningar - uppvisar en språkpositivism. När Alice återberättar sina upplevelser i slutet av romanen gör hon det med en sådan vitalitet och kraft att systern bygger upp en egen fantasi om Underlandet. Detta tolkar Zadworna-Fjellestad som en symbol för berättandets förmåga att entusiasmera och skapa våra egna fiktiva världar med hjälp av litteraturen (Zadworna-Fjellestad 1986: 37). Det är en läsning som jag bara delvis kan hålla med om. Med Zadworna-Fjellestads tolkning blir Alice som mest inflytelserik och aktiv när hon lämnar Underlandet och börjar berätta för sin syster. Själv vill jag hävda att Alices aktörskap är pågående och något som hon ständigt är tvungen att försvara. Ur ett sådant perspektiv är hennes frågor och ifrågasättanden ett aktivt försök att utmana berättarens version av romanen och påverka intrigen i realtid.

För att förstå tyngden i detta maktanspråk kan jag inte bara ta hänsyn till det verbala. Jag måste också undersöka vilken roll kroppen spelar - det vill säga dess fysiska utsträckning i berättelserummet och dess rörelsefrihet - när Alice säkrar sitt aktörskap. Det är något som Zadworna-Fjellestad inte heller gör men som många andra har intresserat sig för under årens lopp, inte minst utifrån ett jungianskt perspektiv med fokus på till exempel den oidipala aspekten av Alices ätande och drickande. ${ }^{7}$ Jarlsdotter-Wikström utmärker sig något i denna skara av kroppsintresserade analytiker eftersom hon främst är intresserad av flickkroppen som uttryck för produktivitet och positivitet. Metamorfoserna av Alices kropp har dels att göra med det identitetsprojekt som Alice utforskar, dels är de en förutsättning för de subversiva inslagen i romanen eftersom "den groteska kroppen” bemäktigar flickan och ger henne en röst (Jarlsdotter-Wikström 2013: 96).

När jag undersöker Alices kropp gör jag det också med övertygelsen att den möjliggör agens och står för positiv produktivitet. ”Det groteska” anser jag däremot vara mer komplext än så. Begreppet "grotesk" använder jag för att markera flickskapets både önskvärda och

\footnotetext{
6 "' There ought to be a book written about me, that there ought! And when I grow up, I'll write one [...]" (Carroll 2015: 29) och “'Come, let’s hear some of your adventures”” (Carroll 2015: 84).

${ }^{7}$ För mer läsning om jungianska perspektiv på Alice hänvisar jag till Donald Rackins analyssamling, Alice’s Adventures in Wonderland. Sense, nonsense and meaning (1991)
} 
icke-önskvärda dubbelhet, det vill säga, att Alice tvingas integrera ytterligheterna i en "duktighets-dualitet" liksom hora-madonna-komplexet måste göra med samhällets motstridiga bild av kvinnlig sexualitet. I Maria Margareta Österholms avhandling Ett flicklaboratorium i valda bitar (2012) är grotesken också dubbel och ligger lika nära de destruktiva, svältande och självskadade flickkropparna som de konstruktiva och subversiva (Österholm 2012: 133-182). Jag förstår Alices relation till "grotesken” likadant. Å ena sidan är den motsatsen till vad hon önskar åstadkomma, det vill säga "lagomheten” som hon använder som måttstock för att definiera sitt flickskap. Å andra sidan är det just med hjälp av kroppens gränsöverskridning och "groteska” karaktär som Alice återerövrar sitt aktörskap. Då jag tidigare ägnat mig åt Alices verbala aktörskap vill jag i analysen nedan avtäcka samspelet mellan metafiktion och Alices fysiska makt. Frågan lyder: vilket inflytande har den groteska kroppen på händelseförloppet?

Något av det första som inträffar när Alice trillar ner i Underlandet är att hon ändrar storleken på sin kropp, detta på grund av att hon vill ut till den vackra trädgården som hon skymtar genom ett hål i väggen. Alice dricker något och blir för liten, äter något och blir för stor. Nästa gång Alice ändrar kroppsstorlek och blir liten igen, beror detta inte på att hon väljer det utan för att hon håller i en solfjäder som visar sig ha en krympande effekt (på flickor men uppenbarligen inte på vita kaniner).

Bristen på kroppskontroll gör det alltså svårt för Alice att orientera sig i rummet. Kroppen sviker henne. Hon ändrar riktning utan att hon vill det och tvingas gå långa omvägar för att nå sin slutdestination, trädgården. Men det dröjer inte länge förrän Alice upptäcker att hennes kropp kan fungera som ett verktyg, att den kan hjälpa och underlätta många situationer när hon har svårt att ta sig fram. Ett exempel är när Alice möts av en hotfull skara underlandsdjur efter att ha blivit liten nog att smita ut ur kaninens hus. Hon inser att hon inte måste vänta på att de ska säga åt henne vad hon ska göra utan att hon på eget bevåg kan springa därifrån (Carroll 2015: 33). Vid ett annat tillfälle blir tårarna (som hon till en början bannar eftersom de avslöjar hur rädd och liten hon är) ett sätt att förflytta sig då hon simmar genom dem med underlandsdjuren efter sig i släptåg: "Alice led the way, and the whole party swam to the shore” (Carroll 2015: 20). Gråten, eller rättare sagt känslorna, är vad som möjliggör denna rörelsefrihet eftersom det ofta är utifrån ett känslotillstånd som Alice (re)agerar i såväl ord som sina handlingar. Som tydligast framgår detta i slutet av romanen när Alice, med allt större självförtroende, ifrågasätter Underlandets brist på mening och logik - så till den grad att hela världen så småningom upplöses:

'Stuff! and nonsens!' said Alice loudly. 'The idea of having the sentence first!'

'Hold your tounge!' said the Queen, turning purple.

'I won't!' said Alice.

'Off with her head' the Queen shouted at the top of her voice. Nobody moved.

'Who cares for you?' Alice said, (she had grown to her full size by this time.) 'You're nothing but a pack of cards.' (Carroll 2015:100)

Kopplingen mellan Alices storlek och Alices självförtroende är slående. I själva verket är den dubbelriktad vilket innebär att Alice växer av att trotsa (som i scenen ovan) men också blir trotsigare av det faktum att hon växer. När Alice så småningom förstår hur kroppen påverkas av hennes mat- och vätskeintag kan hon äta precis så mycket svamp som är nödvändigt för att 
bli stor nog att fatta mod att kliva in i Hertiginnans hus när hon som liten inte vågade (Carroll 2015: 53). Litenheten associerar Alice med något svagt, hjälplöst och barnsligt som hon är trött på att bli förknippad med. Längtan efter att bli stor har ingenting att göra med denna fysiska förändring utan bottnar i en förhoppning om att få tillgång till ett annat språk när hon växer upp. Hennes mål är nämligen att skriva ner sina upplevelser själv en dag: ”'There ought to be a book written about me, that there ought! And when I grow up, I'll write one - but I'm grown up now' she added in a sorrowful tone; 'at least there's no room to grow up any more here.' (Carroll 2015: 29). Det sista Alice tillägger visar dock att det inte är bra att växa för mycket, att bli för stor. Lagomheten - motsatsen till grotesken - är än en gång vad Alice eftersträvar.

Kroppens föränderlighet har således en ambivalent effekt på Alices aktörskap: å ena sidan en brist på kroppskontroll som inte bara är osmidig utan även obehaglig och ger upphov till självförakt och identitetsproblem. Växandet blir ett uttryck för Alices känslor kring att vara barn, vilket hon på flera sätt upplever som ett problem, något som hindrar henne, språkligt såväl som kroppsligt, i hennes äventyr. Å andra sidan är föränderligheten något som Alice lär sig att bemästra och kan använda till sin fördel när hon orienterar sig i Underlandet. Särskilt viktig blir den fysiska föränderligheten när hennes verbala förmåga inte räcker till eller, som den lika ofta gör, skapar fler problem. Lösningen blir kroppen. Att växa eller krympa. Gå därifrån. Nonsenstematiken som har en så försvårande effekt på Alices språkliga förmåga, har betydligt mindre - för att inte säga något alls - inflytande på kroppen, vilken snarare förstärker och återerövrar hennes aktörskap.

\section{Att läsa mellan raderna på metafiktion}

Som jag inledningsvis var noga med att påpeka finns huvudsakligen två sätt att definiera metafiktion. Antingen som en receptionsteoretisk effekt som slår in när läsaren tillägnar sig romanen eller som ett påfallande stilgrepp/tema inuti romanen. I min läsning av Alice har jag använt mig av den senare beskrivningen. Jag har förutsatt att metafiktionen är en redan befintlig dimension av romanen för att undersöka vad detta kan generera för andra läsningar. Jag har alltså läst mellan raderna på metafiktionen och analyserat vad den har fått för tematiska konsekvenser, vad den exponerat och aktualiserat. Resultatet blev en läsning av romanens gestaltning av aktörskap och flickskap. Jag har kunnat visa att Alices medvetenhet om sig själv som huvudperson i Underlandet har betydelse för hennes möjlighet att påverka berättelseintrigen, hur hon med hjälp av språket och kroppen lyckas återerövra sitt hotade aktörskap liksom hur omständigheterna försvåras på grund av att hon är flicka. Därmed har jag också kunnat visa att flickskapet är ett av de bärande elementen i den dramaturgiska utvecklingen. Samtliga av dessa iakttagelser har varit möjliga eftersom jag valt att undersöka inte bara metafiktionen utan dess relationer till makt och flickskap.

Det här menar jag öppnar för ett tredje sätt att förstå metafiktion, som ett slags läsning, en tolkningshorisont mot vilken vi kan få syn på och diskutera ytterligare teman. Om analysen stannar vid att enbart identifiera romanens metafiktiva inslag blir den genast förutsägbar och därmed ointressant. Det är vad Zadworna-Fjellestad gör. Hon ger exempel på exempel på romanens metafiktiva karaktär för att kort därefter konstatera samma sak: romanen är metafiktiv, eller som hon hellre kallar det, ”duplex” eftersom den tematiserar läsningen. Även 
Iché och Waugh har svårt att ta analysen till en ny nivå efter att först ha pekat ut metafiktionen och sedan dragit slutsatsen att den gör läsaren medveten om läsakten samt lär hen att vara kritisk mot det betecknande språkets verklighetsanspråk. Som jag ser det är deras receptionsteoretiska tillämpning av metafiktionen tvärtom för oberäknelig och därmed alltid hypotetisk.

Vad jag vill föreslå är att istället använda metafiktionen metodologiskt. I Alice avslöjar metafiktionen en maktordning som inte bara går att härleda till läsarens relation till läsning, vilket är vad Iché föreslår. ${ }^{8}$ Med min analys har jag velat visa att den även kan höja medvetenheten kring till exempel makt i förhållande till genus, språk och kroppslighet.

Det är alltså ytterligare en applikation av metafiktionsbegreppet som jag föreslår vilket gör att metafiktion kan förstås enligt dessa tre led:

1) Som metod, ett sätt att exponera teman i en text

2) Som element inuti texten

3) Som effekt som kan uppstå hos den som läser texten

De två sista leden känner vi igen från tidigare definitionsdiskussioner. Vad som tillkommit är det första. För att metafiktionen inte ska stanna i ett cirkelresonemang runt sig själv och läsakten tror jag att denna tredelade användning av begreppet är nödvändig. Det innebär att vi genom att förutsätta att metafiktionen är något som mer eller mindre finns i berättelsen kan analysera vilka andra teman den aktualiserar. Den här artikeln ser jag som ett första steg mot ett nytt användningsområde för metafiktionen - som en metod, ett sätt att läsa mellan raderna.

\section{Referenser}

Carroll, Lewis (2015), Alice's adventures in Wonderland and through the looking-glass and what Alice found there. [New ed.] London: Bounty books.

Deleuze, Gilles (1990), The logic of sense. New York: Columbia University Press.

Howard, Jeffery (2015) "What is the use of a book... without pictures? Images and words in Alice's Adventures in Wonderland”, The Explicator, Vol.73(1), p.13.

Iché, Virginie (2016). "Submission and Agency, or the Role of the Reader in the First Editions of Lewis Carroll's Alice's Adventures in Wonderland (1865) and Through the Looking-Glass (1871)". Cahiers victoriens et édouardiens [En ligne], 84 Automne |2016, mis en ligne le 01 novembre 2016, consulté le 26 septembre 2017. URL : http://cve.revues.org/2962 ; DOI : 10.4000/cve.2962 [170926]

Jarlsdotter Wikström, Jenny (2013). ”Blivandet och den groteska flickkroppen i Lewis Carrolls Alice's adventures in Wonderland”, i Söderberg, Eva, Maria Österlund \& Bodil Formark (red.), Flicktion : perspektiv på flickan i fiktionen. Malmö: Universus Academic Press, s. 88-101.

McCallum, Robyn (1999), "Very advanced texts: metafictions and experimental work”. Understanding children's literature / edited by Peter Hunt. S. 138-150.

Rackin, Donald (1991), Alice's adventures in Wonderland and Through the looking glass: nonsense, sense, and meaning. New York: Twayne.

\footnotetext{
8 " the reader of the Alice books is simultaneously urged to follow the rules that are brought to her attention and invited to discard the passive role traditionally ascribed to her, thereby becoming a more active reader whose agency enhances her emotional, and probably aesthetic, response to the books she reads“ (Iché 2016:13).
} 
Söderberg, Eva, Maria Österlund \& Bodil Formark (red.) (2013), Flicktion: perspektiv på flickan i fiktionen. Malmö: Universus Academic Press.

Waugh, Patricia (1988[1984]), Metafiction: the theory and practice of self-conscious fiction. London: Routledge.

Zadworna-Fjellestad, Danuta (1986), Alice's adventures in Wonderland and Gravity's rainbow: a study in duplex fiction. Diss. Stockholm: Stockholm universitet.

Österholm, Maria Margareta (2012), Ett flicklaboratorium i valda bitar: skeva flickor i svenskspråkig prosa från 1980 till 2005. Diss. Uppsala: Uppsala universitet. 